\title{
Impact of Audit Committee on Organizational Performance of Listed Hotels and Travels in Sri Lanka
}

\author{
Saseela Balagobei (Corresponding author) \\ PhD Scholar, Faculty of Post Graduate Studies \\ University of Jaffna, Sri Lanka \\ E-mail: saseelas@yahoo.com \\ Thirunavukkarasu Velnampy \\ Professor in Accounting, Faculty of Management Studies and Commerce \\ University of Jaffna, Sri Lanka
}

Received: August 4, 2018 Accepted: November 17, 2018 Published: November 29, 2018

doi:10.5296/ijafr.v8i4.13467

URL: https://doi.org/10.5296/ijafr.v8i4.13467

\begin{abstract}
The audit committee is one of the key elements in the corporate governance structure that helps to control and monitor management in the organization. The aim of this study is to investigate the impact of audit committee on organizational performance of listed hotels and travels in Sri Lanka. The sample consists of 15 listed hotels and travels in Sri Lanka. In this study, data was collected from secondary sources and hypotheses are examined by using Pearson's correlation and multiple regression analysis (Eviews). The results reveal that audit committee attributes such as AC independence, AC experts and AC meetings have a significant impact on organizational performance of listed hotels and travels in Sri Lanka. Further audit committee size is not found to have a significant impact on the organizational performance. The findings could be useful to regulators in other jurisdiction who are looking at ways to enhance the effectiveness of $\mathrm{AC}$, overall firm governance and enhance the organizational performance.
\end{abstract}

Keywords: Audit Committee, Organizational performance, Audit committee independence, Audit committee experts, Audit committee meetings 


\section{Introduction}

The audit committee is one of the key elements in the corporate governance structure that helps control and monitor management (Ruzaidah and Takiah, 2004). The committee plays a vital role in monitoring the organization's operation and internal control system with the purpose of protecting the interest of the shareholders. The audit committee (AC) contributes to the development of the strategic plan of the company and is expected to provide input and recommendations to the board with regard to any financial or operational matters. Hence, it is recognized that an effective audit committee would focus on improving the company performance and competitiveness, particularly in a changing business environment which is beyond the control of the company (Charan, 1998; Craven and Wallace, 2001). An effective audit committee is expected to focus on the optimization of shareholders' wealth and prevent the maximization of personal interests by the top management (Wathne and Heide, 2000).

The primary role of the audit committee is to oversee the firm's financial reporting process, the review of financial reports, internal accounting controls, the audit process and, more recently, its risk management practices (Klein, 2002).

The main focus of audit committees is to strengthen transparency, promote effective enforcement, and identify needs for training and education for directors and key players of an organization. In March 2013, the Securities and Exchange Commission of Sri Lanka and the Institute of Chartered Accountants of Sri Lanka developed the Code of the Best Practices of Corporate Governance, which provides guidelines on the formation of the audit committee, particularly with respect to size, independence, duties and responsibilities of members to ensure good practices of corporate governance. Detailed guidance on the scope and functions of the audit committee can be found in the Code of Best Practice on Audit Committees issued by the Institute of Chartered Accountants of Sri Lanka in 2002.

Porter and Gendall (1993) discussed audit committee development in Canada, the United States, the United Kingdom, Australia and New Zealand, identifying unexpected corporate failure and corporate malpractice as the primary stimuli to their development. Teoh and Lim (1996) also explained the establishment of audit committees in Malaysia as a response to corporate scandals.

Performance measurement refers to the process of measuring the action's efficiency and effectiveness (Neely, Gregory \& Platts, 1995). Performance measurement is the transference of the complex reality of performance in organized symbols that can be related and relayed under the same circumstances (Lebas, 1995).

The hotel and travels industry is a decisive player in promoting tourism industry in Sri Lanka. Incubating market centrism has received particular attention in the modern business world as a mode of reaping higher business performances. According to the Central Bank of Sri Lanka (2014), the contribution of hotels and restaurants to the country's Gross Domestic Product is increased by $11.5 \%$. The accommodation facilities prevailing in the hotel industry in Sri Lanka are dominated by tourist hotels. 
According to Sri Lanka's Tourism Authority, the country has a target of 2.2 million visitors for 2016, which would be a $26 \%$ growth compared with 2015. The Tourism Authority's statistics show that Sri Lanka has welcomed 1.7 million visitors as of October, a $14.6 \%$ increase compared with the same time period last year. Through the efforts to help Sri Lanka's tourism industry grow, the country's hotel demand has increased $3.5 \%$ based on October 2016 year-to-date data. Supply, however, has also increased (+4.2\%), with around 900 new rooms added to the market in the first ten months of the year. Therefore the objective of this study is to investigate the impact of audit committee on organizational performance of listed hotels and travels in Sri Lanka during the period of 2012 to 2016.

\section{Problem of the Statement}

The audit committee helps to management to achieve the set goals of the organization, some of which include ensuring that management fulfils its responsibilities in preparing financial reports and improvement in financial performance.

Although many Sri Lanka listed companies had appointed an audit committee as in many other Asian countries (OECD White Paper 2003), a transparent procedure was absent in the determination of directors' remuneration in them (Senaratne and Gunaratne, 2007). The prominence of audit committees in Sri Lankan companies may have been associated with the dominance of accounting professionals in the boards of these companies and the developed accounting profession in Sri Lanka (Senaratne, 2007). However, the appointment of a nomination committee to oversee board appointments including succession planning and performance evaluation of directors is not yet mandatory for listed companies except for licensed commercial banks for which it is mandatory under the Central Bank Direction. It is questionable why the Listing Rules have not made the establishment of a nomination committee mandatory. A proper and transparent procedure on board appointments is a key to have an effective board as the roles and responsibilities of directors underpin the task of corporate governance. The lack of transparency in the board appointments has also been found as a negative corporate governance feature in many Sri Lankan listed companies (Senaratne and Gunaratne, 2007). Hence, this area needs special attention.

To address this issue this study was undertaken to explore the answer to the following research question: To what extent audit committee impacts on organizational performance?

\section{Theoretical Background, Literature Review and Hypotheses Development}

The audit committee plays a vital role in corporate governance regarding the organization's direction, control, and accountability. The study viewed the corporate governance from different perspectives in addition to different theoretical frameworks.

\subsection{Theoretical Background}

\subsubsection{Agency Theory}

The principal agent relationship has brought some problems which include: agency cost and information asymmetry. Agency theory assumes that the interest of the principal and agent varies and that the principal can control or reduce this by giving incentives to the agent and 
incurring expenses from activities designed to monitor and limit the self-interest activities of the agent (Jensen and Meckling, 1976; Hill and Jones, 1992). According to Bonazzi and Islam (2006) the principal will ensure that the agent acts in the interest of the principal by giving the agent incentives and by monitoring activities of the agent. Among the measures established to reduce the self-serving nature of the agent is an independent AC. Therefore in order to reduce information asymmetry, there is the need for governance mechanisms such as board subcommittees composed of directors with the appropriate attributes such as independence, expertise and experience to prevent or reduce the selfish interest of the agent (Wiseman et al., 2012).

\subsubsection{Stewardship Theory}

Stewardship theory suggests that managers are concerned about the welfare of the owners and overall performance of the company, this contradicts agency theory which believes that agents are self-centered and individualistic (Donaldson and Davis, 1991). The theory suggests that managers will work hard toward the attainment of the goals of owners (Boyd et al., 2011). Based on assumptions of stewardship theory, Ntim (2009) argued that firm performance will be enhanced if the executive have more powers and are trusted to run the firm. The theory suggests that having majority executive directors on a committee will increase effectiveness and produce superior result than majority independent directors on a committee (Al Mamun et al., 2013). This could be as a result of the technical knowledge of the executive directors about the company and industry (Ntim, 2009). Stewardship theory assumes that the steward is capable of unifying the different interests of stakeholders and that the steward willingly act in a way that will protect the interest and welfare of others (Hernandez, 201

\subsection{Literature Review and Hypotheses Development}

According to the Code of best practice on corporate governance (2013) issued by Issued jointly by the Securities and Exchange Commission of Sri Lanka and the Institute of Chartered Accountants of Sri Lanka, the audit Committee should be comprised of a minimum of two independent non-executive directors or exclusively by non-executive directors, a majority of whom should be independent, whichever is higher. The guideline further requires that the chairman of the committee should be a non- executive director, appointed by the board.

It is argued that any difference in organizational performance related to corporate governance is more than likely related to the differences in audit committee attributes. According to the existing literature the key audit committee attributes such as audit committee size, independence, expertise and audit committee meeting frequency is examined with organizational performance.

\subsubsection{Audit Committee Size}

In order to make an audit committee effective in controlling and monitoring top management activities, the audit committee must have enough members to carry out their responsibilities (Vinten and Lee, 1993). 


\section{MInstitute ${ }^{\text {Mech }}$}

International Journal of Accounting and Financial Reporting

ISSN 2162-3082

2018, Vol. 8, No. 4

Findings of prior research on the association of audit committee size and organizational performance are not conclusive. Dalton et al. (1999) find that audit committees become ineffective if their size is either too small or too large. An audit committee with a large number of members tends to lose focus and be less participative compared to those of a smaller size. On the other hand, an audit committee with a small number of members lacks diversity of skills and knowledge, and hence becomes ineffective. An audit committee of the right size would allow members to use their experience and expertise for the best interest of stakeholders.

Jensen (1993) and Lipton and Lorsch (1992) suggest that large boards can be less effective than small boards. The idea is that when boards become too big, agency problems increase within the board and the board becomes more symbolic and less a part of the management process.

However, some researchers (Pincus et al., 1989; Einchenseher and Shields, 1985; Menon and Williams, 1994), find a weak association between the size of the audit committee and a company's performance. Although results do not provide strong support to the monitoring function of an audit committee, the positive relationship between size of an audit committee and firm performance is supported by the argument in resource dependence theory (Pierce and Zahra, 1992). Under resource dependency theory, the effectiveness of an audit committee increases when the size of the committee increases, because it has more resources to be devoted to address issues faced by the company.

\subsubsection{Audit Committee Independence}

There are only few studies that examined the association between AC independence and firm performance, found out positive relationship between size of audit committee size and firm performance (Dey, 2008; Nuryanah and Islam, 2011; Yasser et al., 2011). On the other hand, there are some studies that discovered a negative association between audit committee independence and variables representing firm performance. Dar et al. (2011) analyze corporate governance and firm performance a case study of Pakistan oil and gas companies listed in Karachi Stock Exchange during the period of 2004-2010 and find that AC independence has a negative relationship with firm performance

Independence of audit committee members has been the focus of most of the prior work. A common expectation is that independent audit committee directors would ensure better financial reporting (SEC, 1999), and the expectation is generally supported by existing empirical evidence (Abbott et al., 2000; Beasley et al., 2000). The independence of AC makes it more objective in monitoring the transparency of financial report and the committee is unbiased toward the executive thereby reducing agency problem between executive and other shareholders.

Based on a sample of financial institutions from G8 countries, Yeh et al. (2011) reported that financial institutions with more independent directors on $\mathrm{AC}$ have better performance during the recent global financial crisis. In addition, Woidtke and Yeh (2013) reported that fully independent $\mathrm{AC}$ and $\mathrm{AC}$ with majority independent directors is associated with enhanced in 
formativeness of accounting earnings. Chan and $\mathrm{Li}$ (2008) found performance of companies to be positively related with the presence of expert independent directors (expert independent directors defined as top executive of other listed firms) on AC.

\subsubsection{Audit Committee Financial Expertise}

Audit committee characteristics that might influence the performance relates to the financial expertise which consists of both experience and education. According to Krishnan and Visvanathan (2008) accounting expertise within boards that are characterized by strong governance contributes to greater monitoring by the audit committee and leads to enhanced conservatism.

The need for expert directors on the AC was emphasized as a result of prior financial crises and previous corporate scandals (Güner et al., 2008). Davidson et al. (2004) report that market valuation of a firm is positively related with appointment of a director with finance expertise on AC. Ghafran and O'Sullivan (2013) found that investors value the presence of $\mathrm{AC}$ and they perceive the appointment of expert director on AC positively. The presence of accounting or finance expert on AC will enhance the quality of financial reporting (Abbott et al., 2004) and internal control oversight (Krishnan and Lee, 2009). Furthermore, the presence of accounting or finance expert will help a company to prevent the incidence of accounting misstatement, help reduce possibility of litigation against the company and reduce the attention of regulators on the company. The effectiveness of members of the AC in discharging their functions depends on their level of expertise in accounting and finance (Raber, 2003). The various scandals, the nature of operations and assets of finance companies make the appointment of accounting or finance expert very important to finance companies. The presence of expert directors on $\mathrm{AC}$ enhances the effectiveness of $\mathrm{AC}$ in performing its monitoring function (Carcello et al., 2011).

Although the presence of expert is associated with enhanced controls and reduced chances of accounting manipulations (Krishnan, 2005; Dhaliwal et al., 2006), the ability of a company to attract accounting or finance experts depends on the quality of governance arrangements in a particular company (Krishnan and Lee, 2009). In addition, the effect of expertise of directors on AC may not be significant for all types of companies and may vary with company's lifecycle stage (Carcello et al., 2011).

The complexity of accounting and auditing issues facing companies requires the AC to have members that have expertise in accounting and finance (Abbott et al., 2004). Expertise is required so that the directors will be able to understand audit risk and measures to prevent and detect those risks, understand financial statements and financial reporting issues including issues that involve management's judgment and in case of dispute between external auditor and management, the directors will be able to understand the basis of the disagreement and reconcile between the parties (Dezoort, 1998). Using a sample of government linked companies in Malaysia, Hamid and Aziz (2012) found that there is significant positive impact on performance when $\mathrm{AC}$ committee has directors with accounting and finance background. The directors on AC need technical expertise and experience so that they can participate in audit task schedule and planning which will enable 
them to support external auditor concern and to be able to justify them in the board meetings. Conversely, it is suggested that expertise of directors is not necessary as the lack of technical expertise of the directors will be compensated by the presence of external auditor (Cohen et al., 2002).

DeZoort and Salterio (2001) argue that the audit committee's financial expertise increases the likelihood that detected material misstatements will be communicated to the audit committee and corrected in a timely fashion. Rashidah and Fairuzana (2006) report a positive association between the audit committee's financial expertise and firm performance.

\subsubsection{Frequency of Audit Committee Meetings}

Prior research uses frequency of meetings to measure audit committee activeness (Menon and Williams, 1994; McMullen and Raghunandan, 1996; Collier and Gregory, 1999). Findings suggest that an audit committee that meets more frequently provides a more effective oversight and monitoring mechanism on financial activities, which include the preparation and reporting of the company financial information. It is evident from prior research that audit committees of companies with financial difficulties do not hold meetings as frequently as those without financial difficulties (McMullen and Raghunandan, 1996). Hence, the frequency of meetings has a significant positive relationship with audit committee effectiveness (Collier and Gregory, 1999; Song and Windram, 2000). This evidence is in line with the guidelines proposed by the Cadbury Committee (1992) in the UK, the BRC (1999) in the USA, and the Best Practice Code of Corporate Governance in Malaysia (MICG, 2001). These guidelines require audit committees to meet not less than three times a year. A properly planned meeting schedule would ensure the timeliness of audit committee decisions parallel to the audit cycle and the issuance of financial statements.

The effectiveness of an audit committee in carrying out its monitoring role of financial reporting process and internal control requires regular meetings (Vafeas, 1999). The meetings which need to be held at least three or four times a year must be clearly structured and well controlled by the chairman (Hughes, 1999; McMullen and Raghunandan, 1996). A regular and well controlled meeting would assist audit committees in examining the accounting and related internal control system, and in keeping top management informed of the committee's cautious actions (McMullen and Raghunandan, 1996). A related executive director would provide explanations on procedures and issues that may have arisen (Hughes, 1999). Khanchel (2007) shows there is a significant positive association between audit committee meeting and firm performance of 624 US listed and non-financial firms for the period of 1994-2003 by using multiple regression analysis.

Rateb (2018) investigates the effect of audit committee characteristics on the company's performance. The sample consists of 165 non-financial companies listed on the Amman Stock Exchange (ASE) over the period 2014-2016. The results of the study show that the audit committee size, independence and gender diversity have a significant positive relationship with firm's performance, whereas experience and frequency of meetings has an insignificant association. 


\section{Macrothink}

International Journal of Accounting and Financial Reporting

ISSN 2162-3082

2018, Vol. 8, No. 4

Ida \& Asunga (2016) discusses the impact of audit committee on the performance of public traded stocks on the Ghana Stock exchange since this is crucial in protecting the interest of shareholders. The purpose of this paper is to examine the association between the characteristics of audit committees and performance of firms. This study revealed a relationship between the characteristics of the audit committees and the performance of the firms. Meanwhile, the number of independent members on the audit committee had no influence on the performance of the firms. However, the number of independent members of the audit committee with finance or accounting degrees impacted negatively on the firm's performance.

According to Ahmed (2014), Corporate governance is very important in our business world today, especially after the frequent non-stop worldwide financial crises. Strong corporate governance is now considered a basic condition to accept and register an organization in most of the Stock Exchange Markets all over the world. The audit committee plays a major role in corporate governance regarding the organization's direction, control, and accountability. As a representative of the board of directors and main part of the corporate governance mechanism, the audit committee is involved in the organization's both internal and external audits, internal control, accounting and financial reporting, regulatory compliance, and risk management. This paper focuses on the audit committee's powers, functions, responsibilities, and relationships within the framework of corporate governance.

Based on the above discussion, the following hypotheses are developed:

$\mathrm{H}_{1}$ : Audit committee size significantly influences organizational performance.

$\mathrm{H}_{2}$ : Audit committee independence significantly influences organizational performance.

$\mathrm{H}_{3}$ : Audit committee expert significantly influences organizational performance.

$\mathrm{H}_{4}$ : Audit committee meetings significantly influence organizational performance.

\section{Research Methodology}

The research methodology focuses on the research process, kind of tools and procedures to be used. This study tends to analyze the impact of audit committee on organizational performance.

\subsection{Sample and Data}

The population of the study comprises firms listed under hotel and travels sector in Colombo Stock Exchange (CSE). CSE is the only one share market in Sri Lanka and has 295 companies representing 20 business sectors as at 30th September 2017, with a Market Capitalization of Rs. 2,919.7 Bn. Since the number of hotels and travels companies listed on the main market was only 38 , only 15 companies were are selected as sample of this study based on market capitalization.

The study used secondary data that was collected from the published financial statements of the companies available from the web site of Colombo Stock Exchange during the period of 2012 - 2016. The two most important and fundamental characteristics of any measurement 


\section{1l Macrothink}

International Journal of Accounting and Financial Reporting

ISSN 2162-3082

2018, Vol. 8, No. 4

procedure are reliability and validity. In this study secondary data was extracted from audited annual report of the listed companies as fairly accurate and reliable. Therefore, these data may be considered as reliable for the study. Necessary checking and cross checking were done while scrutinizing information and data from the secondary sources. Therefore the researcher satisfied with the content and construct validity, then it was decided to continue the analysis.

\subsection{Model Specification}

A multiple linear regression model attempts to investigate the influence of audit committee on stock market return. The regression was performed by using statistical program Eviews 9. Specifically, the study was operated based on the following research model:

$$
\text { Tobin's } \mathrm{Q}=\beta_{0}+\beta_{1} \mathrm{ACS}+\beta_{2} \mathrm{ACI}+\beta_{3} \mathrm{ACFE}+\beta_{4} \mathrm{ACM}+\beta_{5} \mathrm{FS}+\varepsilon
$$

Where:

$\beta_{0,}, \beta_{1}, \beta_{2} \beta_{3}, \beta_{4}, \beta_{5}-$ Regression coefficient

ACS - Audit committee size

ACI- Audit committee Independence

ACFE - Audit committee Financial Expertise

ACM - Audit committee meetings

FS - Firm size

$\varepsilon-$ Error term

\subsection{Selection of Dependent and Control Variables}

Prior studies on firm performance used different measures of performance such as ROE, ROA, Tobin's Q efficiency (Kim and Rasiah, 2010), EPS, stock price and dividend payable to measure performance of companies (Ponnu, 2008) with no consensus on the best method of measuring performance (Ntim, 2009). "Market measures of performance are more objective than accounting based measures; they are also affected by some factors beyond control of the management" (Gani and Jermias, 2006, p. 303). High Tobin's Q ratio shows that the markets have a positive perception about the performance of the firm (Haniffa and Hudaib, 2006; Ntim, 2009). This study used market measures of performance (Tobin's Q) similar to prior studies on corporate governance and performance of finance companies such as Zulkifli and Abdul Samad (2007), Kim and Rasiah (2010), Sufian and Habibullah (2010), Al-Saidi and Al-Shammari (2013) and Ong and Gan (2013). In addition, following prior studies, firm size was used as control variable (Sufian and Habibullah, 2010). 
Table 1. Operationalisation of variables

\begin{tabular}{lll}
\hline Concept & Variables & Measurement \\
\hline $\begin{array}{l}\text { Audit } \\
\text { committee }\end{array}$ & Audit committee size & \begin{tabular}{l} 
Number of audit committee members \\
\cline { 2 - 3 }
\end{tabular} \\
\cline { 2 - 3 } & $\begin{array}{l}\text { Audit committee } \\
\text { Independence }\end{array}$ & $\begin{array}{l}\text { Proportion of independent directors to } \\
\text { audit committee size }\end{array}$ \\
\cline { 2 - 3 } & $\begin{array}{l}\text { Audit committee } \\
\text { Financial Expertise }\end{array}$ & $\begin{array}{l}\text { Proportion of audit committee members } \\
\text { with financial expertise to the total number } \\
\text { of audit committee members }\end{array}$ \\
\cline { 2 - 3 } & $\begin{array}{l}\text { Audit } \\
\text { meetings }\end{array}$ & $\begin{array}{l}\text { Number of meetings held in financial year } \\
\text { Total market value of the firm divided by } \\
\text { its total asset value }\end{array}$ \\
\hline $\begin{array}{l}\text { Organizational } \\
\text { performance }\end{array}$ & Tobin's Q & The natural logarithm of total assets \\
\hline Control variable & Firm size &
\end{tabular}

\section{Empirical Results}

\subsection{Descriptive Analysis}

Table 2 represents the descriptive statistics of audit committee variables and organizational performance measured by Tobin's Q in Sri Lanka during the period of 2012 to 2016.

Table 2. Descriptive statistics

\begin{tabular}{lllllll}
\hline & & $\mathrm{AC}_{-}$ & $\mathrm{AC}_{-}$ & $\mathrm{AC}_{-}$ & $\mathrm{Firm}_{-}$ & \\
& $\mathrm{AC} \_S i z e$ & independence & Expert & Meetings & Size & Tobin's_Q \\
\hline Mean & 3.000 & 0.777 & 0.916 & 4.183 & 9.246 & 0.943 \\
\hline Median & 3.000 & 0.750 & 1.000 & 4.000 & 9.264 & 0.756 \\
\hline Maximum & 4.000 & 1.000 & 1.000 & 6.000 & 9.874 & 2.721 \\
\hline Minimum & 2.000 & 0.500 & 0.000 & 3.000 & 8.484 & 0.236 \\
\hline Std. Dev. & 0.576 & 0.177 & 0.278 & 0.469 & 0.386 & 0.593 \\
\hline Skewness & -0.021 & 0.153 & -3.015 & 1.571 & -0.494 & 1.354 \\
\hline Kurtosis & 2.716 & 1.675 & 10.090 & 6.177 & 2.462 & 4.145 \\
\hline
\end{tabular}

Table 2 presents the descriptive statistics of all variables employed in this study. On average companies have the audit committee size of 3 . The maximum available audit members on the board in the sample are 4 . The standard deviation is only 0.576 (aprox.) audit members. 


\section{MlMacrothink}

International Journal of Accounting and Financial Reporting

ISSN 2162-3082

2018, Vol. 8, No. 4

Profile analysis shows that companies have the audit independence of $77 \%$ (aprox) on average. This table also shows that the average audit committee expert of $91.66 \%$ with a standard deviation of 0.278 and has a wide range from 1 to 0 . Audit meeting has the average of 4.183 held per year with the standard deviation of 0.469. Average firm size is 9.246 with standard deviation of 0.386 . Tobin's Q 0.943 is indicating average stock market performance of sample companies during selected study period. There is a highest standard deviation of organizational performance (Tobin's Q) and lower audit committee independence.

\subsection{Correlation Analysis}

This study employs a correlation analysis to discover the association and direction of the variables, mainly audit committee and organizational performance.

Table 3. Correlation matrix

\begin{tabular}{|c|c|c|c|c|c|c|}
\hline \multicolumn{7}{|l|}{ Correlation } \\
\hline Probability & AC_Size & $\begin{array}{l}\mathrm{AC}_{-} \\
\text {Independence }\end{array}$ & $\begin{array}{l}\mathrm{AC}_{-} \\
\text {Expert }\end{array}$ & $\begin{array}{l}\text { Ac_- } \\
\text { Meeting }\end{array}$ & $\begin{array}{l}\text { Firm_ } \\
\text { Size }\end{array}$ & Tobin's Q \\
\hline \multirow[t]{2}{*}{ AC_Size } & 1.000 & & & & & \\
\hline & ----- & & & & & \\
\hline \multicolumn{7}{|l|}{$\mathrm{AC}_{-}$} \\
\hline \multirow[t]{2}{*}{ Independence } & -0.552 & 1.000 & & & & \\
\hline & 0.000 & ----- & & & & \\
\hline \multirow[t]{2}{*}{ AC_Expert } & 0.105 & -0.380 & 1.000 & & & \\
\hline & 0.424 & 0.002 & ----- & & & \\
\hline \multirow[t]{2}{*}{ AC_Meeting } & -0.200 & 0.209 & 0.118 & 1.000 & & \\
\hline & 0.124 & 0.108 & 0.368 & ----- & & \\
\hline \multirow[t]{2}{*}{ Firm_Size } & 0.298 & 0.033 & -0.178 & 0.201 & 1.000 & \\
\hline & 0.020 & 0.796 & 0.171 & 0.122 & ----- & \\
\hline \multirow[t]{2}{*}{ Tobin's_Q } & -0.128 & -0.214 & 0.251 & -0.124 & 0.115 & 1.000 \\
\hline & 0.326 & 0.094 & 0.050 & 0.344 & 0.380 & ----- \\
\hline
\end{tabular}




\section{MlMacrothink}

International Journal of Accounting and Financial Reporting ISSN 2162-3082

According to the table 03 the value of correlation between audit committee expert and Tobins' $Q$ is 0.251 which is significant at 0.05 levels; indicates that there is a weak positive association between audit committee expert and Tobins' $Q$.

Other audit committee variables such as audit committee size, audit committee independence and audit committee meeting have an insignificant relationship with organizational performance measured by Tobins' $Q$ while firm size is not significant with organizational performance at 0.05 levels $(\mathrm{r}=0.115, \mathrm{p}>0.05)$.

\subsection{Multiple Regression Analysis}

In order to examine the impact of audit committee on organizational performance, Least Squares method by using E-views is performed in this study. Results of the analysis are presented in the Table 4.

Table 4. Multiple regression analysis

\begin{tabular}{lllll}
\hline Variable & Coefficient & Std. Error & t-Statistic & Prob. \\
\hline C & -2.201456 & 1.738673 & -1.266171 & 0.2109 \\
\hline AC_Size & -0.249983 & 0.139299 & -1.794579 & 0.0783 \\
\hline AC_Independence & -0.361327 & 0.161942 & -2.231213 & 0.0298 \\
\hline AC_Experts & 0.584334 & 0.279866 & 2.087911 & 0.0415 \\
\hline AC_Meeting & -0.327421 & 0.161032 & -2.033258 & 0.0470 \\
\hline Firm_Size & 0.611950 & 0.203855 & 3.001895 & 0.0041 \\
\hline R-squared & 0.284095 & Mean dependent var & 0.943843 \\
\hline Adjusted R-squared & 0.217808 & S.D. dependent var & 0.593377 \\
\hline S.E. of regression & 0.524792 & Akaike info criterion & 1.643011 \\
\hline Sum squared resid & 14.87198 & Schwarz criterion & 1.852446 \\
\hline Log likelihood & -43.29034 & Hannan-Quinn criter. & 1.724933 \\
\hline Prob(F-statistic) & 0.002351 & Durbin-Watson stat & 0.869669 \\
\hline
\end{tabular}


According to the table 04, coefficient of determination for audit committee variables $\left(\mathrm{R}^{2}\right)$ is 0.2840 which denotes that $28.40 \%$ of the observed variability in organizational performance can be explained by the differences in the variables such as audit committee size, audit committee independence, audit committee expert, audit committee meeting and firm size. The remaining $71.60 \%$ of the variances is related to the other variables which are not depicted in this model. In this analysis, F statistic is $4.285, \mathrm{p}<0.05$, indicated that the model is significant. It means that the regression results are acceptable for this analysis and all variables (audit committee size, audit committee independence, audit committee expert, audit committee meeting and firm size) jointly in the model significantly affect the organizational performance at $5 \%$ significant level.

Among the all four audit committee variables considered in the analysis, only three audit committee variables have a significant impact on organizational performance which are audit committee independence, audit committee expert and audit committee meeting. Audit committee independence has a significant negative influences on organizational performance $(\mathrm{B}=-0.361327, \mathrm{p}<0.05)$, similar pattern is observed in audit committee meeting that has a significant negative impact on organizational performance $(B=-0.327421, p<0.05)$. Further audit committee expert has a significant positive influences on organizational performance $(B=0.584334, p<0.05)$. Firm size has a significant positive influences on organizational performance $(B=0.611950, p<0.05)$. The coefficient of audit committee size shows that audit committee size has no significant impact on organizational performance. Durbin-Watson statistic which is a diagnostic statistic, tests for the presence of auto-serial correlation in the data. Table 04 shows that Durbin-Watson statistic is 0.869669 , indicates that the presence of positive auto serial correlation.

By using the multiple regression analysis the hypotheses are examined in this study. Hypothesis $\left(\mathrm{H}_{1}\right)$ stated that audit committee size significantly influences organizational performance. According to the table 04, there isn't a significantly impact of audit committee size on organizational performance measured by Tobin's $\mathrm{Q}(\mathrm{p}=0.0783>0.05)$, as a result $\mathrm{H}_{1}$ is not supported. It is supporting the previous finding of Mak and Kusnadi (2005) that could not provide any relationship between the size of $\mathrm{AC}$ and firm performance in Malaysia and Singapore.

Hypothesis $\left(\mathrm{H}_{2}\right)$ stated that audit committee independence significantly influences organizational performance. Since the p-value of t test for audit committee independence is $0.0298<0.05$ which illustrates that there is a significant negative impact of audit committee independence on organizational performance, as a result $\mathrm{H}_{2}$ is supported. The result is consistent with the findings of previous research such as Dar et al. (2011).

Hypothesis $\left(\mathrm{H}_{3}\right)$ states that audit committee experts significantly influences organizational performance Since the p-value of $t$ test for audit committee experts is $0.0415<0.05$ which illustrates that there is a significant positive impact of audit committee experts on organizational performance, as a result $\mathrm{H}_{3}$ is supported. The results are collaborated with previous studies such as Hamid and Aziz (2012) and Rashidah and Fairuzana (2006). 


\section{$\triangle$ Macrothink}

International Journal of Accounting and Financial Reporting

ISSN 2162-3082

2018, Vol. 8, No. 4

Hypothesis $\left(\mathrm{H}_{4}\right)$ stated that audit committee meeting significantly influences on organizational performance. Since the p-values of $t$ test for audit committee meeting are $0.0470<0.05$ which illustrated that there is a significant negative impact of audit committee meeting on organizational performance, as a result $\mathrm{H}_{4}$ is supported.

\section{Conclusion}

The overall goal of this study is to investigate the impact of various $\mathrm{AC}$ attributes, such as the $\mathrm{AC}$ size, AC independence, AC expertise and AC meetings on the organizational performance measured by Tobin's $\mathrm{Q}$ for the listed hotels and travels. Audit committee attributes such as $\mathrm{AC}$ independence, $\mathrm{AC}$ experts and $\mathrm{AC}$ meetings have a significant impact on organizational performance of listed hotels and travels in Sri Lanka. The results of the study suggest that the features of audit committees in Sri Lanka are relevant in terms of the organizational performance.

The findings of the study suggest that more independent directors to the AC leads to the weaker firm performance measured by Tobin's Q. The reason behind this can be explained by the insufficient technical knowledge of independent directors and consequently their failure to make a good recommendation to the board. Such a result is also consistent with Al Mamun et al. (2013) who discovered that including more executive directors to the committee leads to higher effectiveness and reaching of superior results than those reached by the majority of independence directors. On the contrary, this result is inconsistent with the agency theory which emphasizes the independence of boards and committees in order to reduce the agency costs.

The findings could be useful to regulators in other jurisdiction who are looking at ways to enhance the effectiveness of AC, overall firm governance and enhance investors' confidence in the firms. Future studies could examine other committee attributes such as size, individual characteristics of the directors on the committee and the internal processes of the committee. Furthermore, the study used secondary data; future studies could use primary data or a combination of primary and secondary data. Finally, future studies could consider taking a qualitative approach to examine the impact of $\mathrm{AC}$ attributes on organizational performance.

\section{References}

Abbott, L. J., Park, Y., \& Parker, S. (2000). The effects of audit committee activity and independence on corporate fraud. Managerial Finance, 26, 55-67.

Abbott, L. J., Parker, S., \& Peters, G. F. (2004). Audit committee characteristics and restatements. Auditing: A Journal of Practice and Theory, 23(1), 69-87.

Al-Baidhani, A. M. (2014). The Role of Audit Committee in Corporate Governance: Descriptive Study. SSRN Electronic Journal.

Al-Mamun, A., Yasser, Q. R., \& Rahman, M. A. (2013). A discussion of the suitability of only one vs more than one theory for depicting corporate governance. Modern Economy, 4(1), $37-48$. 


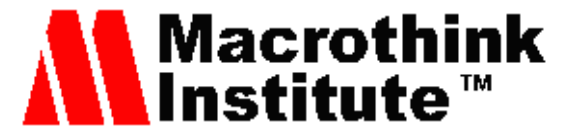

International Journal of Accounting and Financial Reporting

ISSN 2162-3082

2018, Vol. 8, No. 4

Beasley, M. S., Carcello, J. V., Hermanson, D. R., \& Lapides, P. D. (2000). Fraudulent financial reporting: consideration of industry traits and corporate governance mechanisms. Accounting Horizons, 14, 441-54.

Blue Ribbon Committee. (1999). Report and Recommendations of the Blue Ribbon Committee in Improving the Effectiveness of Corporate Audit Committee. New York Stock Exchange, New York, NY.

Bonazzi, L., \& Islam, S. M. N. (2006). Agency theory and corporate governance: a study of the effectiveness of the board in their monitoring of the CEO. Journal of Modeling in Management, 2(1), 7-23.

Boyd, K. B., Haynes, K. T., \& Zona, F. (2011). Dimensions of CEO-board relations. Journal of Management Studies, 48(8), 1892-1923.

Carcello, J. V., Hermanson, D. R., \& Ye, Z. S. (2011). Corporate governance research in accounting and auditing: insights, practice implications, and future research directions. $A$ Journal of Practice and Theory, 30(3), 1-31.

Carcello, J. V., Neal, T. L., Palmrose, Z. V., \& Scholz, S. (2011). CEO involvement in selecting board members, audit committee effectiveness, and restatements. Contemporary Accounting Research, 28(2), 396-430.

Chan, K. C., \& Li, J. (2008). Audit committee and firm value: evidence on outside top executives as expert-independent directors. Corporate Governance: An International Review, 16(1), 16-31.

Charan, R. (1998). How Corporate Boards Create Competitive Advantage. Jossey-Bass, San Francisco, CA.

Cohen, J. R., Krisnamoorthy, G., \& Wright, A. M. (2002). Corporate governance and audit process. Contemporary Accounting Research, 19(4), 573-594.

Collier, P., \& Gregory, A. (1999). Audit Committee in Large UK Companies. The Institute of Chartered Accountants, London.

Craven, K. S., \& Wallace, W. A. (2001). A framework for determining the influence of the corporate board of directors in accounting studies. Corporate Governance, 9(1), 2-23.

Dalton, D. R., Daily, J., Johnson, L., \& Ellstand, A. E. (1999). Number of directors and financial performance: a meta-analysis. Academy of Management Journal, 42, 674-86.

Dar, L. A., Naseem, M. A., Rehman, R. U., \& Niazi, G. S. (2011). Corporate Governance and Firm Performance a Case Study of Pakistan Oil and Gas Companies Listed in Karachi Stock Exchange. Global Journal of Management and Business Research, 11(8), 1-10.

Davidson, W. N., Xie, B., \& Xu, W. (2004). Market reaction to voluntary announcement of audit committee appointments: the effect of financial expertise. Journal of Accounting and Public Policy, 23(4), 279-293.

Dey, A. (2008). Corporate governance and agency conflicts. Journal of Accounting Research, 46(5), 1143-1181. 


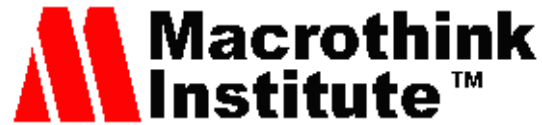

International Journal of Accounting and Financial Reporting

ISSN 2162-3082

Dezoort, F. T. (1998). An analysis of the experience effects on audit committee members oversight judgment. Accounting, Organization and Society, 23(1), 1-21.

DeZoort, F. T., \& Salterio, S. E. (2001). The effects of corporate governance experience and financial reporting and audit knowledge on audit committee directors' judgments. Auditing: A Journal of Practice \& Theory, 20, 31-48.

Donaldson, L., \& Davis, J. H. (1991). Stewardship theory or agency theory: CEO governance shareholder returns. Australian Journal of Management, 16(1), 49-65.

Einchenseher, J. W., \& Shields, D. (1985). Corporate director liability and monitoring preferences. Journal of Accounting \& Public Policy, 4(1), 13-31.

Ghafran, C., \& O'Sullivan, N. (2013). The governance role of audit committee: reviewing a decade of evidence. International Journal of Management Reviews, 15(4), 381-407.

Guner, A. B., Malmendier, U., \& Tate, G. (2008). Financial expertise of directors. Journal of Financial Economics, 88(2), 323-354.

Hamid, A., \& Aziz, R. (2012). Impact of the amendments of Malaysian code of corporate governance (2007) on governance of GLCs and performanc. World Academy of Science, Engineering and Technology, 6(11), 612-617. Retrieved September 11, 2013, from www.waset.org/ journals/waset/v71/v71-302.pdf

Hernandez, M. (2012). Toward an understanding of the psychology of stewardship. Academy of Management Review, 37(2), 172-193.

Hill, C. W. L., \& Jones, T. M. (1992). Stakeholder-agency theory. Journal of Management Studies, 29(2), 131-154.

Hughes, R. (1999). The rise and rise of audit committee. Accountancy, 123(1266), 59.

Ida, G., \& Asunga, B. (2016). The Effect of Audit Committees on the Performance of Firms Listed on the Ghana Stock Exchange. IOSR Journal of Business and Management, 18(2), $55-62$.

Jensen, M. (1993). The modern industrial revolution, exist, and the failure of internal control systems. Journal of Finance, 48, 831-880.

Jensen, M. C., \& Meckling, W. H. (1976). Theory of firm: managerial behavior, agency costs and ownership structure. Journal of Financial Economics, 3(4), 305-360.

Khanchel, I. (2007). Corporate governance: Measurement and determinants analysis. Managerial Auditing Journal, 22(8), 740-760.

Krishnan, G., \& Visvanathan, G. (2008). Does the SOX definition of an accounting expert matter? The association between audit committee directors' accounting expertise and accounting conservatism. Contemporary Accounting Research, 25(3), 827-858.

Krishnan, J. (2005). Audit quality and internal control: an empirical analysis. The Accounting Review, 80(2), 649-675. 


\section{Mll Macrothink}

International Journal of Accounting and Financial Reporting

ISSN 2162-3082

2018, Vol. 8, No. 4

Krishnan, J., \& Lee, J. E. (2009). Audit committee financial expertise, litigation and corporate governance. Auditing: A Journal of Practice and Theory, 28(1), 241-261. Retrieved April 15, 2012, from http://ssrn.com/abstract $1 / 41316278$

Lebas, M. (1995). Performance measurement and performance management. International Journal of Production Economics, 41(1-3), 23-35.

Lorsch, J. W. (1992). A modest proposal for improved corporate governance. Business Lawyer, 48, 59-77.

Mak, Y. T., \& Kusnadi, Y. (2005). Size really matters: Further evidence on the negative relationship between board size and firm value. Pacific-Basin Finance Journal, 13, 301-318.

Malaysian Institute of Corporate Governance. (2001). Malaysian Code on Corporate Governance. Finance Committee on Corporate Governance, Kuala Lumpur, January.

McMullen, D. A., \& Raghunandan, K. (1996). Enhancing audit committee effectiveness. Journal of Accountancy, 182(2), 79-81.

Menon, K., \& Williams, J. D. (1994). The use of audit committee for monitoring. Journal of Accounting \& Public Policy, 13, 121-39.

Neely, A., Gregory, M., \& Platts, K. (2005). Performance measurement system design: A literature review and research agenda. International Journal of Operations \& Production Management, 25(12), 1128-1263.

Ntim, C. G. (2009). Internal corporate governance structures and firm financial performance: evidence from South African listed companies. Unpublished PhD thesis, University of Glasgow, Glasgow.

Nuryanah, S., \& Islam, S. M. N. (2011). Corporate governance and performance: Evidence from an emerging market. Malaysian Accounting Review, 10(1), 17-42.

Pierce, J., \& Zahra, S. (1992). Board composition from a strategic contingency perspective. Journal of Management Studies, 29, 411-38.

Pincus, K., Rusbatsky, M., \& Wong, J. (1989). Voluntary formation of corporate audit committees among NASDAQ firms. Journal of Accounting \& Public Policy, 8239-65.

Porter, B., \& Gendall. (1993). An International Comparison of the Development and Role of Audit Committees in the Private Corporate Sector. European Accounting Association Conference, Turku, Finland.

Raber, R. W. (2003). The role of good corporate governance in overseeing risk. Corporate Governance Advisor, 11(2), 11-16.

Rashidah, A. R., \& Fairuzana, H. M. (2006). Board, audit committee, culture and earnings management: Malaysian evidence. Managerial Auditing Journal, 21(7), 783-804.

Rateb, M. A. (2018). Audit Committee Effectiveness and Company Performance: Evidence from Jordan. Accounting and Finance Research, 77(2), 48-60. 


\section{Mll Macrothink}

International Journal of Accounting and Financial Reporting

ISSN 2162-3082

2018, Vol. 8, No. 4

Ruzaidah, R., \& Takiah, M.I. (2004). The effectiveness of audit committee in monitoring the quality of corporate governance. Corporate Governance: An International Perspective, Malaysian Institute of Corporate Governance (pp. 154 -75), Kuala Lumpur.

SEC. (1999). Audit Committee Disclosure, Securities and Exchange Commission. US Government Printing Office, Washington, DC.

Sharma, V., Naiker, V., \& Lee, B. (2009). Determinants of audit committee meeting frequency: Evidence from a voluntary governance system. Accounting Horizons, 23, 245-263.

Song, J., \& Windram, B. (2000). The Effectiveness of Audit Committees: Experience from UK. Napier University Business School, Edinburgh.

Teoh, H. Y., \& Lim, C. (1996). An Empirical Study of the Effects of Audit Committees, Disclosure of Non-audit Fees and Other Issues on Audit Independence: Malaysian Evidence. Journal of International Accounting, Auditing and Taxation, 5(2), 231-248.

Vafeas, N. (1999). Board meeting frequency and firm performance. Journal of Financial Economics, 53(1), 113-42.

Vinten, G., \& Lee, C. (1993). Audit committee and corporate control. Managerial Auditing Journal, 8(3), 113-42.

Wathne, K. H., \& Heide, J. B. (2000). Opportunism in inter-firm relationship: forms, outcomes and solutions. Journal of Marketing, 64(4), 36-51.

Wiseman, R. M., Cuevas-Rodríguez, G., \& Gomez-Mejia, L. R. (2012). Towards a social theory of agency. Journal of Management Studies, 49(1), 202-222.

Woidtke, T., \& Yeh, Y.-H. (2013). The role of the audit committee and the informativeness of accounting earnings in East Asia. Pacific-Basin Finance Journal, 23, 1-24.

Yasser, Q. R., Entebang, H., \& Mansor, S. A. (2011). Corporate governance and firm performance in Pakistan: The case of Karachi Stock Exchange (KSE). Journal of Economic and International Finance, 3(8), 482-491.

Yeh, Y.-H., Chung, H., \& Liu, C.-L. (2011). Committee independence and financial institution performance during the 2007-2008 credit crunch: evidence from a multi-country study. Corporate Governance: An International Review, 19(5), 437-458.

\section{Copyright Disclaimer}

Copyright for this article is retained by the author(s), with first publication rights granted to the journal.

This is an open-access article distributed under the terms and conditions of the Creative Commons Attribution license (http://creativecommons.org/licenses/by/4.0/) 